\title{
Social and emotional learning in education and care policy in Croatia
}

\author{
Maja Ljubetic $^{1}$, Toni Maglica² \\ ${ }^{1}$ Department of Pedagogy, University of Split, Croatia \\ ${ }^{2}$ Department of Early and Preschool Education, University of Split, Croatia
}

\begin{tabular}{l}
\hline Article Info \\
\hline Article history: \\
Received Jan 24, 2020 \\
Revised Jun 10, 2020 \\
Accepted Jul 18, 2020 \\
\hline
\end{tabular}

\section{Keywords:}

Educational policies

Positive outcomes

Practice

Social-emotional competences

Social-emotional learning

\begin{abstract}
Worldwide practises and then scientific research is showing that socialemotional learning represents a highly promising approach for positive development and adjustment, improvement of academic success in children and even prevention of behavioural problems. But despite these findings, there is no systematic approach in the implementation of the social-emotional learning in Croatia, and the practice of it is not yet structured and comprehensive and occurs rather occasionally and spontaneously. This paper is trying to ascertain is there a formal and legal platform for implementing social-emotional learning in the crucial documents that regulate educational and care practises in Croatia. The analysis of the documents was conducted according to the criterium of key social-emotional competencies and the associated social-emotional skills.
\end{abstract}

This is an open access article under the $\underline{C C B Y-S A}$ license.

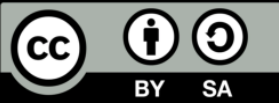

\author{
Corresponding Author: \\ Maja Ljubetic, \\ Department of Pedagogy, \\ University of Split, \\ Poljicka cesta 35, 21000 Split, Croatia. \\ Email: ljubetic@ffst.hr
}

\section{INTRODUCTION}

Social-emotional learning represents a process by which children (and adults) acquire knowledge, opinions and skills to recognize and manage their emotions, set and realize positive goals, show care and concern towards others, establish and maintain positive relationships, bring responsible decisions and efficient management of interpersonal situations [1,2] and make use of one's strengths and overcome difficulties in social and academic tasks [3]. Social and emotional education refers to the educational process by which an individual develops social and emotional competence for personal, social and academic growth and development through curricular, embedded, relational and contextual approaches [4]. The competencies acquired through the process of social and emotional learning are called social and emotional competences and a great number of authors agree on what they represent [5-7]. The Schonert-Reichl, Kitil and Hanson-Peterson classification [8] will be used as the purpose of this paper, which divides social and emotional competencies into five areas:

a. Self-awareness: the possibility of correct recognition of one's owns emotions, thoughts and their impact on behaviour. This also includes a correct evaluation of one's strengths and limitations and possession of well-founded self-confidence and optimism.

b. Self-management: the ability to manage one's own emotions, thoughts and behaviours in different situations. It includes stress management, control over instincts, self-motivation, setting personal goals and perseverance in their realization. 
c. Social awareness: the possibility of consideration from different perspectives, empathizing with persons of different origin, culture, understanding social and ethical norms of conduct, and (re)cognition of resources and support inside a family and educational environment, as well as the community.

d. Relationship skills: the ability to establish and maintain healthy relationships with other individuals and groups. This includes appropriate communication, active listening, partnership, resistance to inappropriate peer pressure, constructive negotiation during conflicts and helping others, as well as asking for help when necessary.

e. Responsible decision-making: the ability to make constructive choices on one's behaviour and social interactions, based on ethical standards, safety and social norms, assessment of different actions and one's own and others' well-being.

Worldwide research suggests that socio-emotional learning represents a highly promising approach in the prevention of behavioural problems, promotion of positive adjustment and improvement of academic success in children [4, 9-14]. Many studies revealed numerous positive outcomes in children whose schools and kindergartens conducted programs of social and emotional learning, such as a significant increase in positive self-attitudes, attitudes towards others and school, social conducts and dealing with problems, and a positive increase in academic performance [15-18]. The positive development of social and emotional competencies in children contributes to better relationships with peers, a higher level of school readiness and general well-being [19]. Social and emotional competencies determine success and general satisfaction with life and all relationships [20]. The children who possess those competencies and associated skills, opinions and beliefs, will be healthier, thoughtful, and ethical, they will bring decisions more responsibly and avoid forms of behaviour with negative consequences like interpersonal violence, drug abuse and abusive behaviour [21, 22]. The children who have mastered pro-social skills and understand others' emotional states perform better at school, rarely manifest their internalized and externalized behavioural problems, possess better physical health and have better self-respect and confidence in people that surround them [23]. Despite all the mentioned advantages, it is surprising that in one of the crucial European document about competences, and that is European Framework of 8 Competencies for Lifelong Learning, none of the eight key competencies adequately addresses social-emotional learning. As Cefai et al. [7] mentioned there is a limited focus on social-emotional learning, and it is treated as merely a sub-dimension of social and civic competence.

Understanding social-emotional child development as one of the crucial ones within a child's overall development and recognizing the fact that in educational and care practice (from kindergarten to higher education) there is no systematic approach in the implementation of the social-emotional learning (SEL), the goal of this paper is to provide a review of the presence of the topic of social-emotional learning within some of the Croatian key documents that regulate educational and care practices in the Republic of Croatia and the presence of topics from the social-emotional development of children inside them (Table 1).

Pupils who stand out in school often continue to be successful long after the end of their academic career. At the core of most cases of academic success and more is the ability of pupils to use their pro-social and emotional behaviours which promote positive and healthy interactions with others and prepare them to skilfully deal with challenges they come across on their way to success are [24].

Assuming that every child's mentioned social-emotional competencies are developed, both presently and in future, the fact that investing in acquiring social-emotional competencies of children and youth is left to the free will of enthusiasts in the institutions of early and preschool education and care, elementary and high schools, is seen as inadequate. Contemporarily, in the context of recent events and the increase in peer violence and violence by pupils (and parents) against educators in the Republic of Croatia, it appears significant to shed light on the lack of systematic social-emotional learning, with the goal of acquiring social and emotional competencies as a protective factor for the mental health of children and youth within the Croatian education system. 
Table 1. Social-emotional skills within specific domains of social-emotional competence (integrated and adapted from CASEL [2] and SSIS SEL [24]

\begin{tabular}{|c|c|}
\hline $\begin{array}{c}\text { SELF-MANAGEMENT } \\
\text { (impulsivity control, stress management, self- discipline, } \\
\text { self-motivation, setting goals) }\end{array}$ & $\begin{array}{c}\text { SOCIAL SKILLS } \\
\text { (communication, social engagement, relationship } \\
\text { development) }\end{array}$ \\
\hline $\begin{array}{c}\text { Listening to others } \\
\text { Respecting rules } \\
\text { Paying attention to one's work } \\
\text { Being calm around others } \\
\text { Expressing one's feelings } \\
\text { Staying calm when pushed or hit }\end{array}$ & $\begin{array}{l}\text { Saying please and thank you } \\
\text { Maintaining eye contact during conversation } \\
\text { Being together with others } \\
\text { Asking others to work with you }\end{array}$ \\
\hline $\begin{array}{c}\text { SELF-AWARENESS } \\
\text { (emotion identification, correct self-perception, strength } \\
\text { recognition, self-confidence, self-efficiency) } \\
\text { Asking for help } \\
\text { Telling others of personal skills } \\
\text { Being positive towards future }\end{array}$ & $\begin{array}{c}\text { RESPONSIBLE DECISION-MAKING } \\
\text { (problem identification, analysis of the situation, problem- } \\
\text { solving, evaluation, reflection, ethical responsibility) } \\
\text { Doing the right things } \\
\text { Answering for your actions } \\
\text { Respecting others' opinions } \\
\text { Doing your share during group work } \\
\text { Hearing different ideas }\end{array}$ \\
\hline $\begin{array}{c}\text { SOCIAL AWARENESS } \\
\text { (understanding diversity, empathy, seeing things from other } \\
\text { perspectives, respect of others) } \\
\text { Doing the right things } \\
\text { Answering for your actions } \\
\text { Respecting others' opinions } \\
\text { Doing your share during group work } \\
\text { Hearing different ideas }\end{array}$ & \\
\hline
\end{tabular}

Reviewing the practice, the authors of the paper conclude that it is clear that the programs of socialemotional learning in kindergartens and elementary schools in the Republic of Croatia are mostly conducted occasionally, in an unorganized manner, and fragmentarily (one or several workshops for a selected sample of educational groups/classes), usually held by expert associates or educators/teachers for whom there is no information available on how much and what way they have been trained for the area of social-emotional learning. One of the positive breakthroughs has been accomplished by the scientists of the Faculty of Education and Rehabilitation Sciences of the University of Zagreb who started a program PATHS-RASTEM in six preschool institutions in Zagreb, Croatia. The program consisted in 37 lectures conducted by educators (one hour, two times a week) directed at 1) understanding feelings and developing self-control, 2) interpersonal problem solving, 3) peer relationships/friendship and 4) developing self-respect in children [25]. The evaluation of the program has shown that after a year of implementation in the preschool institution the pro-social behaviours and emotion regulation in children has improved, while behavioural problems, aggression, peer issues, and hyperactivity have decreased [26]. Researching the area, the cited authors have stated that in the area of preschool education the social and emotional learning is conducted fragmentarily and mostly relies on the readiness and capacities of educators.

Worldwide, the situation is significantly different. Socio-emotional programs (SEL programs) are conducted in thousands of schools and kindergartens of the USA, Great Britain, Australia, the Netherlands and Norway [16]. Moreover, all 50 states of the USA have agreed upon the socio-emotional standards for preschool children, and some states have integrated SEL standards into the learning standards [27]. More than 500 evaluated SEL programs have confirmed changes in the social and emotional skills of the children and young from kindergarten to higher education age. As stated earlier in the introduction, a large number of studies $[16,21]$ have found that social-emotional learning programs can be efficient not only for improving social-emotional skills but also for reducing behavioural problems and improving academic success in children and youth.

\section{RESEARCH METHOD}

Given the presence of serious challenges in this area in the Croatian practice, we were interested to find out if there are legal prerequisites that could enable and key documents that might entice and direct the educational and care practice towards socio-emotional learning. In order to achieve this goal, content analysis method was used. Two independent scientist, authors of this paper, analysed key documents that regulate educational and care practices in the Republic of Croatia and the presence of topics from the social-emotional 
development of children inside them. The analysis covers the following documents: National Curriculum Framework [28]; The Strategy of Education, Science and Technology (2014-2016) [29]; Preschool Education Act [30]; National Curriculum for Early and Preschool Education and Care [31]; Primary and Secondary School Education Act Croatia [32]; Program of inter-subject and interdisciplinary contents of citizenship education for primary and secondary schools [33]. The analysis of the stated documents was conducted according to the criterium of key social-emotional competencies $[1,2,8]$ and the associated social-emotional skills as shown in Table 1.

\section{SOCIAL AND EMOTIONAL LEARNING IN CROATIAN EDUCATIONAL POLICIES}

\section{Republic of Croatia's education system}

The education system in the Republic of Croatia starts in preschool institutions where a year before the enrolments to elementary school (at 5 or 6 years of age) the child is involved in an obligatory preschool program. The primary education starts with enrolment to the first class of the elementary school, and it is obligatory that all children (as a rule it lasts from the age of 6 to 15, and for pupils with multiple developmental disabilities no later than until their 21 years of age). The elementary school lasts for eight years and offers regular and special programs. The education system of the Republic of Croatia allows for a parallel primary education in the form of primary art education (music and dance programs). For children older than 15 who have not finished legally prescribed obligatory primary school there is a system of primary education for adults. The secondary education follows the end of the primary, and the pupils can continue their education in high school institutions which are not obligatory. The secondary education institutions, depending on the type of their educational program, are divided into grammar schools (gymnasiums), vocational schools and art schools. Grammar schools prepare their pupils for the continuation of education, vocational schools enable them to enter the labour market, at the same time offering them a possibility to continue their education, while the art schools enable acquisition of knowledge, development of skills, capacities, and creativity in different artistic areas.

The National curriculum framework for preschool education and care [31] and obligatory and high school education (hereinafter: NOK) from 2010, is a developmental document containing educational and care values, goals, competencies, and principles which represent basic guidelines for planning development and functioning of educational and care institutions. This document, in particular, serves as a basis for the creation of a school curriculum and the creation of subject curricula and other curricula-related documents. The life and work in a contemporary society marked by fast changes and tough competition require new knowledge, skills, competencies, values and opinions, i.e. new competencies of individuals which put the focus on the development of innovation, creation, problem-solving, development of critical opinion, entrepreneurship, informatics literacy, social and other competencies.

The values promoted by NOK meeting the analysis criteria, i.e. are in the areas and competencies from the domain of social-emotional learning, are as follows: knowledge (critical self-reflection and reflection of everything that surrounds an individual), solidarity (sensitivity towards others, family, those who are weak, poor and deprived of rights), identity (among others, respecting diversity) and responsibility which includes active participation in social life, promotion of responsibility towards oneself, others and the world. Out of the six explicitly stated goals in NOK for this paper, we will focus on the following: stimulation of social and moral development, respect of diversity and tolerance, active and responsible participation in the democratic development of society, independence, self-confidence, responsibility and creativity and preparation of students for life-long learning. The present document states inter-subject or interdisciplinary topics, obligatory in all school subjects that can be realized in several ways (integrating them in individual subjects, joint projects or modules).

For this paper, we point to the inter-subject or interdisciplinary contents/modules recommended to be executed in elementary and high schools such as: "Personal and social development", "Citizenship education and care", which can be directly connected the domains of social-emotional competencies [1,2]. The purpose of the inter-subject topic "Personal and social development" is the recognition and critical reflection of a person's personal and social value, responsibility for own behaviour and life, dealing with others and constructive participation in social life, personal and social development, development of communication, organization and social skills and capacities, self-confidence building, collaboration in intercultural situations, decision making and cooperation with others. The inter-subject topic "Citizenship education and care" is focused on the development of democratic awareness of pupils, active and effective involvement in the development of democratic relationships, development of one's own identity, getting to know and respecting others, sensitizing pupils for solving global issues, righteousness, pacifism, etc. The goals of this inter-subject topic are, among others, to develop an awareness of rights, duties, and responsibilities of individuals, social equality ... tolerance and enable students to critically judge social phenomena. 
The analysis of the stated document shows that there are numerous topics and areas which satisfy the predetermined analysis criterion, i.e. fall into the category of competencies from the domain of socialemotional learning $[1,2]$ with a particular emphasis on social skills, social awareness and responsible decision making. Self- management skills (impulsivity control, stress management, self-discipline, self-motivation, goal setting, organization skills) and self-awareness (emotion identification, correct self- perception, strength recognition, self-confidence, and self-efficiency) are either merely brushed upon or almost entirely neglected.

Furthermore, the issue of evaluation and reflection is given extremely little attention (it is explicitly stated only in the inter-subject theme "Entrepreneurship" as follows: "to develop skills of evaluation of others and self- evaluation and critical attitude towards ...". It is the issue of (self)evaluation and reflection of one's own and others' behaviours, events, and situations [34] that appear crucial for change and improvement of behaviour of an individual and even a group. Through a continuous good quality self-evaluation, an individual becomes aware of his inefficient, inappropriate, unacceptable behaviours and associates them with pre-set goals. Given that they usually do not result in the desired outcomes, the individual can change and improve them without fear of losing his own power in the eyes of others.

The Strategy of Preschool, Elementary and High School Education and Care [29] is connected to the Strategic framework for European cooperation in education and training. In line with this strategic framework, the aim, in particular, is to empower early acquisition and support the concept of life-long learning, improve the quality and efficiency within the education and training system, promote equal opportunities, righteousness, social cohesion and active citizenship and empower creativity and innovation on all levels and in all types of education. In the area of early and preschool, elementary and high school education and care, this Strategy set eight goals, however for this paper we will focus only on goal No. 6: To develop a complete system of support for pupils. Namely, in one of the measures for the realization of this goal it is stated as follows: "To create a development of metacognitive, emotional and social skills programs and to incorporate them in the school curriculum, which is in the competence of schools and the implementation is the duty of headmasters, expert associates and teachers". It is evident that the Special expert committee for the creation and implementation of the Strategy gives particular attention to the metacognitive, and emotional and social skills of pupils, and it is, therefore, reasonable to expect that they will be equally treated and implemented in pedagogical practice. The basic documents specifically directed at regulating the practice of early and preschool education and care are The Preschool Education Act [30] and the National Curriculum for Early and Preschool Education and Care [31].

The Preschool Education Act [30] (hereinafter: Act) regulates preschool education and care of preschool-aged children as a part of the system of education and care. It would be unreasonable to expect the Act to explain the area of social-emotional learning in more detail. However, in Article 15 the Act prescribes the obligation to adopt a national curriculum for preschool education and care and a curriculum for kindergartens. The national curriculum sets values, principles, general educational goals and contents for all activities and programs, approaches and working modes with children of early and preschool age, education and care goals according to areas of development and competencies of children.

The National Curriculum for preschool education [31] contains starting points, values, principles, and goals of early and preschool education that represent the backbone of the formation of the educational process and curriculum of every kindergarten, and the system as a whole. This document promotes the planning and functioning of education based on values that should improve intellectual, social, moral, spiritual and motor development of children, which are: knowledge, identity, humanism and tolerance, responsibility and autonomy. Interpreting the values of humanism and tolerance in the National curriculum it reads as follows "...this includes a high level of sensitivity of adults towards children and development of sensitivity of children to others, peers, family, environment and the entire living environment ... Affirmation of humanism and tolerance means creating an educational approach based on compassion, acceptance and mutual support, and enabling children to understand their rights, obligations, and commitments, as well as those of others. In kindergarten, children learn how to recognize and accept their own and other people's needs, respect diversity and build caring relations with others and jointly organize activities that can raise the quality of life of the entire community morally, materially and spiritually... such an approach promotes the inclusion of children with special needs..."

When describing the value of identity, the National curriculum emphasizes that "education and care have to contribute to the creation of the personal, cultural and national identity of a child, help him to form an identity of a "citizen of the world" while preserving his identity... he has to be empowered to be true to himself, develop self-respect, create a positive image of himself and build a feeling of security when meeting new people...". When describing the value of responsibility, it reads as follows "...education and care need to encourage active participation of children in social life and promote their responsibility for the common good, nature and themselves... learning about one's own and others' rights, obligations, ways of actively participating in a community and possibilities to contribute to the common well-being. The value of autonomy, on the other 
hand, stresses the need "to develop autonomous thinking, decision making, and child behaviour. It is developed by encouraging initiative-taking and self-organization of a child in creating his own activities. The child is encouraged to make decisions and choices, exercise his rights, present and stand up for his opinion...". One of the goals of the National Curriculum for early and preschool education and care is "Ensuring the child's welfare" which includes personal, emotional, physical, educational and social welfare. In the context of social and emotional learning, the Curriculum mentions topics such as: enjoying interactions and activities, the openness of the child to the world around him and new experiences, calmness (absence of the feeling of danger, restlessness and concern, child's self-acceptance (non-suppression of emotions, self- acceptance), self-respect and self-awareness, development of personal and social identity, readiness to make decisions regarding his activities, development of personal opinion and actions, evaluation of possible consequences of his actions, initiative-taking and innovation, self-initiative and self-organization of personal activities, reflection and self-assessment of his own actions and achievements. The Curriculum includes encouragement of the child's curiosity and initiative-taking, questioning his ideas, well-reasoned presentation of his ways of thinking the educational welfare, while social welfare consists in understanding and accepting others and their diversities, ethics, solidarity, and the child's tolerance while communicating with others, perception of himself as an important part of the community/environment and responsible behaviour towards himself and others.

Generally speaking, the National curriculum for early and preschool education fosters the development of basic competencies for life-long learning that the Republic of Croatia took over from the European Union (EU). Among those eight competencies we can find "social and citizenship competence" which belongs to the domain of social and emotional learning.

The Primary and Secondary School Education Act Croatia [32] regulates the activity of primary and secondary education in public institutions, lists the EU directives transposed into the legal system of the Republic of Croatia, defines the educational activity, goals and principles of education and care, state pedagogical standard, rights and obligations of pupils, employees of the institutions and parents, network of school institutions, surveillance and control, as well as a whole series of issues related to educational activity in elementary schools and high schools. According to Article 162, school institutions are obliged to comply with their general acts with the provisions of this Act.

In 2014 the Ministry of science, education, and sports adopted the Program of inter-subject and inter-disciplinary contents for the Citizenship education for elementary schools and high schools [33]. Whether it is implemented as a special subject or an inter-subject one, this Program represents a "conceptual, didactical and methodical framework for the development of citizenship competence in elementary schools and high schools". The program expects the schools to improve their approaches based on experience, team, expert, collaboration and workshop learning connected to research, deduction, problem-solving, which, along with acquiring knowledge, allows the development of skills and values. In the description of successful teaching methods of Citizenship education and care it is evident that they should start from pupils' experience, encourage them to take part in joint activities and collaborate to search for and adopt common decisions, and to critically question the effects of these decisions on each of them and the community to which they belong. These methods encourage the development of social-emotional competencies, but social-emotional learning, properly understood, cannot be reduced to citizenship education and as a civic competence, not to simply a social or a cultural competence [4, 7]. Additionally, it is expected to "ensure the conditions of learning in which the pupil questions his strengths and abilities, discovers what his strong points are, acquires selfconfidence, masters and manages the learning process, plans his future development..." It is recommended to continue nurturing open and collaborative communication in class and to create an environment of mutual respect. To contribute to the full development of citizenship competence of a pupil through education and care Citizenship education and care is introduced through obligatory inter-subject implementation. In that part, and related to the goal of this paper, the Program explicitly states as follows: development of communication skills, emotion management (their recognition and appropriate expressing), conflict management (non-violent problem solving), implementation of research projects and volunteering in the local community. Furthermore, in a more detailed elaboration of thematic areas of the contents of citizenship education, for each class individually, one finds 1) Human-legal dimension connected to other dimensions, 2) Political dimension connected to other dimensions, 3) Social dimension connected to other dimensions, 4) Inter-cultural dimension connected to other dimensions, 5) Economic dimension connected to other dimensions and 6) Ecological dimension connected to other dimensions. In each of the stated areas, there are elements of social-emotional competencies, with topics of contents explicitly stated, together with key contents that can be worked on, and learning outcomes. By way of illustration, we find social and communication skills, a person's dignity, emotion management, and teamwork expressly stated as early as in grade one of the elementary school in area 3: Social dimension connected to other dimensions - Social skills and social solidarity. Some of the learning outcomes include: pupil demonstrates the skill of correct presentation, greetings, finds ways to help pupils with special needs, understands acceptable and unacceptable behaviours, develops techniques of teamwork and describes 
the meaning of every person's dignity in his own words. Through a detailed analysis of the entire Program, through elaborations and areas for each education level, one encounters explicitly stated key concepts and outcomes in the form of competencies which are equal to the criteria of social-emotional learning which we have chosen for our analysis. Hence, the Program explicitly lists emotion management, coding and decoding feelings and needs of others, appropriate expression of emotions, empathy, communication skills, resistance to peer pressure, negotiating, argumentation, teamwork, rules, and procedures of conflict management, social solidarity and other.

\section{DISCUSSION}

The success of children, including their academic performance, does not depend as much on the amount of facts they possess, or their precise reading skills, as it does on emotional and social factors, self-confidence and interest, awareness of what behaviour is expected from them and how to manage the instinct that leads to act inappropriately, the ability to wait, follow instructions, turn to teachers for help and express the need to agree with other children [35]. Poor emotional competence precedes numerous subsequent social, emotional and behavioural issues during a child's development [36, 37]. On the other hand, a large body of different reviews and meta-analyses conducted in Europe and the United States have proved the impact of social-emotional learning on positive attitudes towards self and others, positive social behaviours and reduction of different behavioural problems [7,9]. Regarding the educational setting from kindergarten up to high school, studies are consistently documenting a significant positive impact of social-emotional programs on students' behaviour including improved social-emotional competence across the five SEL competencies [2], but also better classroom behaviour, improved academic performance and motivation, enhanced connection to the school, as well decreased bullying, aggression, conduct disorders, stress and anxiety [38-41].

Considering the goal of this paper, which was to determine the presence of social-emotional learning in educational documents, it is clear that there is an "inclination" of the State to create legal and value-oriented prerequisites for the implementation of such a form of learning in the Croatian educational practice. A detailed description of the social-emotional learning is not expected to be found among the fundamental laws in this area, i.e. Preschool education Act [30] and the Primary and Secondary School Education Act [32], but they do provide a legal platform for the implementation of SEL in practice. Therefore, the Primary and Secondary School Education Act [32] prescribes obligatory adoption of a National Curriculum [28] (adopted in 2014), aimed at determining values, principles, general educational goals and contents for all activities, approaches and ways of working with children of early and preschool age, educational goals according to development areas, as well as necessary competencies. It is precisely in the national curricula, strategies, and programs that we find topics specific to the social-emotional learning area, and equality in concepts which prescribe outcomes, goals, and competencies, and are related to social-emotional competencies. The ones that stand out the most are the National Curriculum for Early and Preschool Education [31] and the Program of Inter-Subject and Interdisciplinary Contents of the Citizenship Education for Elementary and High Schools [33] which, apart from the value-oriented aspects and teaching methods, describes in detail the areas, outcomes and competencies which are brought in a direct relationship with the development of social-emotional competencies, for each of elementary and high school grades individually.

On the ground of the analysis of the documents, we can conclude that the documents regulating the educational practice from preschool institutions to elementary and high school constitute a formally legal and value-oriented platform for the integration of social-emotional learning into the obligatory educational process aimed at acquiring and developing the social-emotional competencies of children. But as it was mentioned earlier, the practice of social-emotional learning in Croatia is still not all-encompassing, not yet structured and intentional, but occurs rather occasionally and spontaneously. It is necessary to look into the reasons as to why the social-emotional learning in the Croatian practice is still, as accidental and spontaneous, rather than intentional, and how is it that we still do not possess structured, comprehensive and evidence-based programs of social-emotional learning offered to children at all education level systematically and continuously [26].

Despite numerous scientifically proven benefits on children, the young and the community as a whole, and the formal legal framework enabling and encouraging such a form of learning, in Croatia, there is no systematic and comprehensive practice of implementation of the program of social-emotional learning based on science and/or excellent practice. This is a concerning fact, considering that social-emotional competencies are one of the key aspects of the development of an individual, enabling him to have a full, healthy and balanced life with himself and others within a community. This conclusion about Croatian practices is in line with many of European Union educational systems, where the importance of social and emotional aspects of education is recognised but is not accompanied by a focused and distinct approach to SEL as a core area in the curriculum and interpersonal and intrapersonal competencies are not explicitly stated [42]. 
Part of the answer lies in the fact that it is not enough to have a legal or curriculum background, but the entire social-emotional implementation framework consisted of: structured and integrated curriculum, adequate institutional climate, early intervention, targeted interventions for children in risk, children (student) voices, quality implementation and adaptation, but also staff competence and wellbeing, and parental collaboration and education [7]. Therefore, it is pointed out that adults- parents, teachers, school principals and especially policymakers, must create such an educational context where children and the young will acquire and improve social and emotional competencies from the earliest age. To accomplish this complex task, those adults must have a common framework of action and continuous education in this field [43, 44].

Partnership and collaboration with parents is a key feature of a whole-school approach to social and emotional learning and a crucial element for its effectiveness [45]. Regarding the teachers, while the impact of SEL programs of students has been well documented, little attention has been put on the impact of SEL in enhancing teachers' social and emotional skills [46]. During the university education future teacher received little training on how to promote social and emotional education [47] although it's known: "To reach the students, teach the teachers" $[8,48,49]$. The studies have also documented that principals with social and emotional skills and strong emotional well-being exhibit effective leadership, develop healthy relationships, and establish family and community partnerships that facilitate effective school-wide SEL implementation $[50,51]$. These components are crucial for sustaining positive social, emotional and even academic outcomes for students.

This sort of "cycle" of key adults and their relationship and education determines the quality of an individual's functioning within and for the community, enabling him to continuously grow, develop and reach his own goals while recognizing the right and necessities of others. Solely in such a way, adequate Learning Context [8] can be created, and that means an environment that is safe, caring, supportive, and wellmanaged, an environment that supports a students' development and provides opportunities for practising SEL skills and open to parental and community involvement.

\section{CONCLUSION}

This paper aimed to provide an overview of knowledge about the importance and efficiency of socioemotional learning on the growth and development of children and young people and to trace whether there is a base for its implementation in key Croatian documents governing educational practices from kindergarten to high school. It has been identified that in Croatian laws, documents, strategies and curricula there is a platform for socio-emotional learning, but the implementation is scarce, occasional, more spontaneous than thoughtful and organized. These data were not surprising because other EU countries have similar experiences in the implementation of this kind of learning.

Therefore, there are still many challenges in this area bearing in mind that it is necessary to create a common framework of action and commitment of all stakeholders crucial for socio-emotional learning, and that are children and certainly, the adults surrounding them, primarily parents, teachers and principals, and then policymakers. Only in such a systematic and comprehensive way, it will be possible to provide a learning context and an environment that ensures the full quality of socio-emotional learning and all the benefits it brings.

\section{REFERENCES}

[1] J. Payton, et al., The positive impact of social and emotional learning for kindergarten to eight-grade students: Findings from three scientific reviews. Collaborative for Academic, Social, and Emotional Learning, Chicago, IL, 2008.

[2] CASEL, "Awareness management social awareness social and emotional relationship: social and emotional learning (SEL) competencies,” 2017. [Online]. Available: https://casel.org/wp-content/uploads/2019/12/CASELCompetencies.pdf

[3] C. Sefai and V. Cavioni, Social and emotional education in primary school: integrating theory and research into practice. Springer, London, 2014.

[4] C. Cefai, A. Arlove, M. Duca, N. Galea, M. Muscat, and V. Cavioni, "RESCUR Surfing the Waves: an evaluation of a resilience programme in the early years," Pastor. Care Educ., vol. 36, no. 3, pp. 189-204, 2018.

[5] J. E. Zins and M. J. Elias, "Social and emotional learning: Promoting the development of all students," Journal of Educational and Psychological Consultation, vol. 17, no. 2-3, pp. 233-255, 2007.

[6] Celene E. Domitrovich, et al., "Improving young children's social and emotional competence: a randomized trial of the preschool "PATHS" curriculum," J. Prim. Prev., vol. 28, no. 2, pp. 67-91, 2007.

[7] C. Cefai, P. Bartolo, V. Cavioni, and P. Downes, Strengthening social and emotional education as a core curricular area across the EU: A review of the international evidence. Publications Office of the European Union, Luxembourg, 2018 . 
[8] K. A. Schonert-Reichl, M. J. Kitil, and J. Hanson-Peterson, "To reach the students, teach the teachers: a national scan of teacher preparation and social \& emotional learning," A report prepared for the CASEL, 2017.

[9] R. P. Corcoran, A. C. K. Cheung, E. Kim, and C. Xie, "Effective universal school-based social and emotional learning programs for improving academic achievement: A systematic review and meta-analysis of 50 years of research," Educ. Res. Rev., vol. 25, pp. 56-72, 2018.

[10] J. E. Zins, et al, "The scientific base linking social and emotional learning to school success," Journal of Educational and Psychological Consultation, vol. 17, no. 2-3, pp. 191-202, 2007.

[11] M. Sklad, R. Diekstra, M. De Ritter, J. Ben, and C. Gravesteijn, "Effectiveness of school-based universal social, emotional, and behavioral programs: Do they enhance students' development in the area of skill, behavior, and adjustment?" Psychol. Sch., vol. 49, no. 9, pp. 892-909, 2012.

[12] R. P. Weisberg, K. L. Kumpfer, and M. E. P. Seligman, "Prevention that works for children and youth: An introduction," American Psychologist, vol. 58, no. 6-7, pp. 425-432, 2003.

[13] M. T. Greenberg, et al., "Enhancing school-based prevention and youth development through coordinated social, emotional, and academic learning.," Am. Psychol., vol. 58, no. 6-7, pp. 466-474, 2003.

[14] D. B. Wilson, D. C. Gottfredson, and S. S. Najaka, "School-Based Prevention of Problem Behaviors: A MetaAnalysis," J. Quant. Criminol., vol. 17, no. 3, pp. 247-272, 2001.

[15] M. J. Van Ryzin and C. J. Roseth, "Cooperative learning effects on peer relations and alcohol use in middle school," J. Appl. Dev. Psychol., vol. 64, pp. 101-059, 2019.

[16] R. P. Weissberg, J. A. Durlak, C. E. Domitrovich, and T. P. Gullotta, "Social and Emotional Learning: Past, present, and future”, in J. A. Durlak, R. P. Weissberg, C. E. Domitrovich, T. P. Gullotto, Handbook of social and emotional learning: Research and practice, Guilford, 2015.

[17] C. Blewitt et al., "Social and emotional learning associated with universal curriculum-based interventions in early childhood education and care centers," JAMA Netw. Open, vol. 1, no. 8, e185727, 2018.

[18] J. A. Durlak, et al, "The Impact of Enhancing Students' Social and Emotional Learning: A Meta-Analysis of School-Based Universal Interventions," Child Dev., vol. 82, no. 1, pp. 405-432, 2011.

[19] J. E. Moore, et al., "The effects of exposure to an enhanced preschool program on the social-emotional functioning of at-risk children," Early Child. Res. Q., vol. 32, $3^{\text {rd }}$ Quarter, pp. 127-138, 2015.

[20] J. Gottman, J. Declaire, and D. Goleman, The Heart of Parenting: Raising an emotionally intelligent child, Simon \& Schuster, 1998.

[21] M. J. Elias, J. E. Zins, and R. P. Weissberg, "The need for social and emotional learning," in Promoting Social and Emotional Learning: Guidelines for Educators, 1997.

[22] T. N. Barnes, F. Wang, and K. M. O'Brien, "A meta-analytic review of social problem-solving interventions in preschool settings," Infant Child Dev., vol. 27, no. 5, pp. 1-22, 2018.

[23] A. Brajša Žganec, Dijete i obitelj: emocionalni i socijalni razvoj. Naklada Slap. Zagreb, 2003.

[24] S. N. Elliott, M. D. Davies, J. R. Frey, F. Gresham, and G. Cooper, "Development and initial validation of a social emotional learning assessment for universal screening,” J. Appl. Dev. Psychol., vol. 55, pp. 39-51, 2018.

[25] Ž. Novak, M. Mihić, J. Bašić, and J. Božić, "Provedba predškolskog PATHS-RASTEM programa u Hrvatskojiskustva iz prakse," in Knjiga sažetaka 8. međunarodnog znanstvenog skupa Istraživanja u edukacijskorehabilitacijskim znanostima, vol. 53, no. 9, pp. 287-288, 2012.

[26] J. Mihic, M. Novak, J. Basic, and R. L. Nix, "Promoting social and emotional competencies among young children in Croatia with preschool PATHS," Int. J. Emot. Educ., vol. 8, no. 2, pp. 45-59, 2016.

[27] F. Elliott, et al., SSIS Social-emotional learning. Edition classwide intervention program manual, PsychCorp, 2017.

[28] Nacionalani okvirni kurikulum (National Curriculum Framework), Ministry of Science, education, and Sport, 2010.

[29] Strategija obrazovanja, znanosti i tehnologije 2014-2016 (Strategy of Education, Science and Technology 20142016), Ministry of Science, Education, and Sport, 2014.

[30] Zakon o predškolskom odgoju i obrazovanju (The Preschool Education Act), Narodne novine, 2019.

[31] Nacionalni kurikulum ranog i predškolskog odgoja (National Curriculum for early and Preschool Education and Care), Narodne novine, 2015.

[32] Zakon o odgoju i obrazovanju u osnovnoj i srednjoj školi (Primary and Secondary School Education Act), Narodne novine, 2019.

[33] Program of inter-subject and interdisciplinary contents of citizenship education for primary and secondary schools (in Croatian), Narodne novine, 2014.

[34] W. Glasser, Teorija izbora (Theory of Choice), Alinea, Zagreb, 1997.

[35] D. Goleman, Working with Emotional Intelligence, Bantam Books, 1997.

[36] S. S. Havighurst, A. Harley, and M. Prior, "Building preschool children's emotional competence: A parenting program," Early Educ. Dev., vol. 15, no. 4, pp. 423-448, 2004.

[37] V. Ornaghi, et al., “'Let's Talk about Emotions!' The Effect of Conversational Training on Preschoolers' Emotion Comprehension and Prosocial Orientation," Soc. Dev., vol. 24, no. 1, pp. 166-183, 2015.

[38] C. Yang, et al, "Multilevel associations between school-wide social-emotional learning approach and student engagement across elementary, middle, and high schools," School Psych. Rev., vol. 47, no. 1, pp. 45-61, 2018.

[39] M. Wigelsworth, et al., "The impact of trial stage, developer involvement and international transferability on universal social and emotional learning programme outcomes: a meta-analysis," Cambridge J. Educ., vol. 46, no. 3, pp. 347-376, 2016.

[40] R. D. Taylor, et al, "Promoting positive youth development through school-based social and emotional learning interventions: a meta-analysis of follow-up effects," Child Dev., vol. 88, no. 4, pp. 1156-1171, 2017. 
[41] S. K. Ura, S. M. Castro-Olivo, and A. d'Abreu, "Outcome measurement of school-based SEL intervention follow-up studies," Assess. Eff. Interv., Jul 2019. [Online]. Available: https://doi.org/10.1177/1534508419862619

[42] OECD, Skills for Social Progress: the power of Social and Emotional Skills, OECD Skills Studies, OECD Publishing, 2015.

[43] E. Haymovitz, et al, "Exploring the Perceived Benefits and Limitations of a School-Based Social-Emotional Learning Program: A Concept Map Evaluation," Child. Sch., vol. 40, no. 1, pp. 45-54, 2018.

[44] M. A. Brackett, C. S. Bailey, J. D. Hoffmann, and D. N. Simmons, "RULER: A Theory-Driven, Systemic Approach to Social, Emotional, and Academic Learning," Educ. Psychol., vol. 54, no. 3, pp. 144-161, 2019.

[45] L. Rampazzo, et al., Joint Action on Mental Health and Well-being. Mental Health and School: Situation analysis and recommendations for action, European Union Health Programme, 2016.

[46] V. Cavioni, I. Grazzani, and V. Ornaghi, "Mental health promotion in schools: A comprehensive theoretical framework," International Journal of Emotional Education, vol. 12, no. 1, pp. 65-82, 2020.

[47] K. A. Schonert-Reichl, J. L. Hanson-Peterson, and S. Hymel, "SEL and preservice teacher education," in J. A. Durlak, R. P. Weissberg, C. E. Domitrovich, T. P. Gullotto, Handbook of social and emotional learning: Research and practice, Guilford, 2015.

[48] K. Eklund, et al, "A systematic review of state-level social-emotional learning standards: implications for practice and research," School Psych. Rev., vol. 47, no. 3, pp. 316-326, Sep 2018.

[49] I. Zych and V. J. Llorent, "An intervention program to enhance social and emotional competencies in pre-service early childhood education teachers," Psychol. Soc. Educ., vol. 12, no. 1, pp. 17-30, 2020

[50] J. Mahfouz, et al., "Principals' social and emotional competence: A key factor for creating caring schools," University Park, PA: Edna Bennett Pierce Prevention Research Center, Pennsylvania State University. 2019.

[51] D. C. Wang, D.B., Pollock, K., Hausemann, "Ontario Principals' and Vice-prinicipals' Well-Being and coping strategies in the Context of Work Intensification," in Perspectives of flourishing in schools, K. Chertowski, S, Walker, Ed. New York: Rowman \& Littlefield, pp. 287-304, 2018. 